\title{
Evaluation of the Implementation of Halal Assurance System (HAS) -23000 With Ergonomics and Technometrics Approaches to the Tempe Industry in Cilegon City
}

\author{
W Susihono* \\ Industrial Engineering Department, \\ Engineering Faculty, University of \\ Sultan Ageng Tirtayasa, Banten, \\ Indonesia \\ *Email : susihono@untirta.ac.id \\ H Haryanto \\ Electrical Engineering Department, \\ Engineering Faculty, University of \\ Sultan Ageng Tirtayasa, Banten, \\ Indonesia \\ Email : elektrojos@yahoo.com
}

\author{
A Gunawan \\ Industrial Engineering Department, \\ Engineering Faculty, University of \\ Sultan Ageng Tirtayasa, Banten, \\ Indonesia \\ Email : a68ar@untirta.ac.id \\ I Istianah \\ The Audit Board of The Republic of \\ Indonesia \\ Email : istianah81@Gmail.com
}

\author{
S Mukarromah \\ Industrial Engineering Department, \\ Engineering Faculty, University of \\ Sultan Ageng Tirtayasa, Banten, \\ Indonesia \\ Email : syifamukarromah@gmail.com
}

Abstract-The application of ergonomics in the halalcertified food processing industry is part of the improvement of the production process to produce comfortable and safe working conditions. This working condition can be improved when various human-related problems have been identified using 8 aspects of ergonomics. Contributions of Technoware, Inforware, Humanware and Organware provide additional recommendations that must be given to humans in completing work activities. Technological ability is used as an instrument to determine the company's strategy in running its business. This strategy needs to be developed based on human center design, humans are the main factor in the consideration of work improvement. The design of this study was cross sectional, observations in the halal certified food processing industry were carried out at one time. The object of this research is the halal-certified tempe industry in the city of Cilegon ( $n=50$ industries). The results showed that ergonomic problems exist in these aspects: energy and nutrition, use of muscle, body posture, work environment, and human-machine interaction. While the most dominant Technometric ability that must be improved is Technoware. Evaluation of the implementation of Halal Assurance System (HAS)-23000 needs to be improved on the criteria of: a) Halal policy, b) production facilities, c) written procedures for critical activities, d) products handling that do not meet the criteria, e) management review. Identification of problems using 8 ergonomic aspects complemented by a map of technometric capabilities, able to perfect the implementation of the Halal Assurance System (HAS) -23000 in Halal Certified processed soybean products in the city of Cilegon

Keywords: ergonomics, technometrics, Halal Assurance System, halal products

\section{INTRODUCTION}

Halal certification is a guarantee that the use of materials, production processes and product names are in accordance with Islamic law. The halal certification domain is in the
MUI fatwa commission, while the audit process and registration process are at the MUI LPPOM. LPPOM MUI, both central and provincial, has conducted halal audits for 30 years. The existence of LPPOM MUI is very beneficial for industries that process food, drinks, medicines and cosmetics. Before an industry submits halal certification, the industry must implement the Halal Assurance System (HAS) -23000. Then the implementation of HAS is evaluated through an audit. An audit of HAS implementation will determine the HAS status of the industry. HAS status is important for the industry because the main assessment of an industry before applying for halal product certification is to build a system that guarantees the halal product. A halal audit of a new product can be carried out if the HAS status of the industry is minimal in category B. When the HAS status of the company is in category $\mathrm{C}$, no halal audit can be carried out on the halal product audit produced by the industry.

Industries that have been halal certified must include the halal label [1]. Currently halal has reached the global market $[2,3,4]$, so to ensure the halal of the product it is necessary to consider the industrial supply chain process. The supply chain process for soybean processing industry raw materials is relatively long, because soybean raw materials come from abroad (imports).

The halal assurance system must be implemented by industry and must comply with the Halal Assurance System (HAS)-23000 guidelines. The implementation of Halal Assurance System (HAS) needs to be evaluated periodically to ensure that the policies, procedures, and criteria in the company have been implemented so that there are no deviations or weaknesses of the system being implemented.

LPPOM MUI Banten Province needs to evaluate the implementation of Halal Assurance System (HAS)-23000 in fifty soybean processing industries that have been halal certified. This evaluation is used as a database for 
performance and business strategy improvement. Performance improvements can be done with an ergonomics approach. Ergonomics approach has been done in many previous studies $[5,6,7,8]$. Ergonomics problem identification will be used as a basis for improving working conditions. The application of ergonomics in the halalcertified food processing industry is part of the improvement of the production process in order to produce comfortable and safe working conditions. This working condition can be improved when various human-related problems have been identified using eight aspects of ergonomics.

Analysis of technology adoption that has been carried out by all industries needs to be done to obtain short-term and long-term strategies. The ability of a company to adopt technology has a very significant impact on similar industries [9]. According to the United Economic and Social Commission for Asia and Pacific [10], technology in the production context consists of four components namely facilities, abilities, fact and frame works. The four components can be combined into technometrics [11,12,13].

Optimal technology adoption will have an impact on increasing company productivity. The higher the company's productivity, the more optimal the level of sales to be obtained. Techometric capabilities are used as instruments to determine the company's strategy in running its business. This technology assessment uses the Techometric method [14]. The company's strategy also needs to be based on human center design, where human are the main factor in the consideration of work improvement. Contributions Technoware, Inforware, Humanware and Organware provide additional recommendations that must be given to humans in completing work activities. Technology has become an important element in the development of small industries [15].

\section{RESEARCH METHOD}

The design of this research is cross-sectional, meaning that the object being used as a study is seen at one time. Observations on the halal-certified food processing industry are made at one time. The object of this research is the halalcertified tempe industry in the city of Cilegon $(n=50$ industries). Subjects taken were all halal-certified (population) tempe industries. Data is taken from the website at LPPOM MUI Banten Province (www.lppommuibanten.org). Data is grouped by product type, then field observations are carried out using eleven criteria in the Halal Assurance System (HAS).

Identification of ergonomic problems uses eight aspects of ergonomics: energy/nutrition, muscle use, posture, work environment, time conditions, socio-cultural, information, and human-machine interface. Eight aspects are used as indicators in reviewing ergonomics problems in the halal-certified soybean processing industry. The dominant problem is chosen and then given recommendations to improve working conditions.

Technology adoption is measured using a Techometric instrument. With this Technometrics instrument, technology adoption is broken up into 4 parts namely Technoware (T), Humanware $(\mathrm{H})$, Inforeware (I) and Organware $(\mathrm{O})$. The value of each ability of the four components is then measured and then made a comparison map. The comparison map will show the components that need to be improved and developed. The comparison map will provide recommendations for the short and long term.

\section{RESULT AND DISCUSSION}

The Government of Cilegon City has an annual allocation of funding in the form of assistance to small industries to assist halal certification. Halal certification is a part that must be done by the industry. The food industry especially processed soybean products need to maintain halal certification. Halal certification aims to ensure that the production process is free from contaminants that are not allowed. Ingredients that are not allowed include pork and its derivatives, alcohol, and even ingredients that are still doubtful halal.

In Cilegon, there are fifty soybean processing industries that have been halal certified from LPPOM MUI Banten province. In its implementation, after obtaining halal certification, the industry needs to maintain its business processes in accordance with the commitments agreed in (Borang E), those are to maintain raw materials, use only those registered in LPPOM MUI Banten province, and only use raw materials that are registered at the auditor's visitation. This commitment is carried out for 2 years or as long as halal certification is still valid (two years).

Form E contains the commitment and statement of responsibility of the company to comply with the rules set by LPPOM MUI. These regulations include: a) halal certification requirements: policies, procedures and criteria (HAS-23000), b) continuous implementation of the Halal Assurance System, c) submitting periodic reports (every 6 months) to LPPOM MUI, d) requests for approval to LPPOM MUI if there is a change in the materials used in the certified product, e) registration of halal certification for each product development, with the same brand and new production facilities, as well as the use of the certified product, f) willingness to receive inspection or visit LPPOM MUI, even without prior notice, g) willingness to take samples of products and materials needed, for the purposes of laboratory analysis and bear the costs of laboratory analysis, h) providing all information related to halal certification, including information on all materials used, product formulas, production processes and implementation Halal Assurance System (HAS), i) list submission material for all the latest certified products that have been signed before the Halal certificate is distributed. If it has not been done, LPPOM MUI has the right to withhold Halal Certification, j) the use of Halal Certificate for two years; and willingness to extend halal certificates, by reapplying no later than 3 (three) months before the validity period of the Certificate expires, k) Announcement to the public at large of Halal Certificates that have expired and not extended, and 1) the inclusion of the LPPOM MUI logo on packaging of products that have been halal MUI-centric.

During the two years of holding halal certification, the industry is obliged to guarantee that the implementation of Halal Assurance System (HAS) continues. In 2018, there were 50 halal certified product industries in Cilegon City, which are spread in several areas in Cilegon City. Almost all 
of the soybean processing industry products are in the form of tempeh.

TABLE I. Processed Halal SOYBEEN Products ARE HALAL IN CiLEgON City ( $\mathrm{N}=50$ IndustRIES)

\begin{tabular}{|c|c|c|c|}
\hline $\begin{array}{l}\text { No. Halal } \\
\text { Certificate }\end{array}$ & $\begin{array}{l}\text { Product } \\
\text { Name }\end{array}$ & $\begin{array}{l}\text { No. Halal } \\
\text { Certificate }\end{array}$ & $\begin{array}{c}\text { Product } \\
\text { Name }\end{array}$ \\
\hline 17190039630518 & Tempe Sujono & 17190039880517 & $\begin{array}{l}\text { Tempe } \\
\text { Dhika }\end{array}$ \\
\hline 17190039640518 & $\begin{array}{l}\text { Tempe Jaqi } \\
\text { Jaya }\end{array}$ & 17190039890518 & Tempe Jos \\
\hline 17190039650518 & $\begin{array}{c}\text { Tempe } \\
\text { Karyudi }\end{array}$ & 17190039900518 & Tempe Win \\
\hline 17190039660518 & Tempe Sugino & 17190039910518 & $\begin{array}{c}\text { Tempe Mas } \\
\text { Lani }\end{array}$ \\
\hline 17190039670518 & Tempe Ojolali & 17190039920518 & Tempe JK \\
\hline 17190039680518 & $\begin{array}{l}\text { Tempe } \\
\text { Bukhori }\end{array}$ & 17190039930518 & $\begin{array}{c}\text { Tempe Mas } \\
\text { Joko }\end{array}$ \\
\hline 17190039690518 & $\begin{array}{c}\text { Tempe } \\
\text { Casmadi }\end{array}$ & 17190039940518 & $\begin{array}{c}\text { Tempe Pak } \\
\text { Min }\end{array}$ \\
\hline 17190039700518 & $\begin{array}{c}\text { Tempe Murni } \\
\text { Jaya }\end{array}$ & 17190039950518 & $\begin{array}{l}\text { Tempe } \\
\text { caruby }\end{array}$ \\
\hline 17190039710518 & $\begin{array}{l}\text { Tempe Mang } \\
\text { Dul }\end{array}$ & 17190039960518 & $\begin{array}{l}\text { Tempe } \\
\text { Super }\end{array}$ \\
\hline 17190039720518 & Tempe Ares & 17190039970518 & $\begin{array}{c}\text { Tempe } \\
\text { Mandiri } \\
\text { Jaya }\end{array}$ \\
\hline 17190039730518 & $\begin{array}{l}\text { Tempe } \\
\text { Sumber } \\
\text { Rezeki }\end{array}$ & 17190039980518 & $\begin{array}{c}\text { Tempe } \\
\text { Aziz }\end{array}$ \\
\hline 17190039740518 & $\begin{array}{c}\text { Tempe } \\
\text { Sofiudin }\end{array}$ & 17190039990518 & $\begin{array}{c}\text { Tempe Pak } \\
\text { Iyan }\end{array}$ \\
\hline 17190039750518 & Arul tempe & 17190040000518 & Tempe SM \\
\hline 17190039760518 & Tempe Doyok & 17190040010518 & $\begin{array}{c}\text { Tempe } \\
\text { TOP }\end{array}$ \\
\hline 17190039770518 & $\begin{array}{c}\text { Tempe } \\
\text { Tasripin }\end{array}$ & 17190040020518 & Tempe WH \\
\hline 17190039780518 & $\begin{array}{c}\text { Tempe } \\
\text { Sambilawang }\end{array}$ & 17190040030518 & $\begin{array}{l}\text { Glewer } \\
\text { Tempe }\end{array}$ \\
\hline 17190039790518 & Gibran Tempe & 17190040040518 & $\begin{array}{l}\text { Sidomulyo } \\
\text { Tempe }\end{array}$ \\
\hline 17190039800518 & $\begin{array}{l}\text { Tempe Talita } \\
\text { Jaya }\end{array}$ & 17190040050518 & $\begin{array}{l}\text { Tempe } \\
\text { Memed } \\
\text { Joss }\end{array}$ \\
\hline 17190039810518 & $\begin{array}{c}\text { Tempe Dedi } \\
\text { Purwanto }\end{array}$ & 17190040060518 & $\begin{array}{l}\text { Tempe } \\
\text { Tanto }\end{array}$ \\
\hline 17190039820518 & Tempe Heri & 17190040070518 & $\begin{array}{c}\text { Tempe } \\
\text { Coyo } \\
\text { Makmur }\end{array}$ \\
\hline 17190039830518 & OK Tempe & 17190040080518 & $\begin{array}{c}\text { Tempe } \\
\text { Roni }\end{array}$ \\
\hline 17190039840518 & $\begin{array}{c}\text { Tempe } \\
\text { Pekalongan }\end{array}$ & 17190040090518 & $\begin{array}{c}\text { Tempe } \\
\text { Fahmy Jaya }\end{array}$ \\
\hline 17190039850518 & Tempe Allam & 17190040100518 & $\begin{array}{c}\text { Tempe } \\
\text { Pekalongan }\end{array}$ \\
\hline 17190039860518 & Tempe Koja & 17190040110518 & $\begin{array}{l}\text { Tempe } \\
\text { Kumis }\end{array}$ \\
\hline 17190039870518 & $\begin{array}{c}\text { Tempe Mang } \\
\text { Juli }\end{array}$ & 17190040120518 & $\begin{array}{l}\text { Tempe } \\
\text { Tono }\end{array}$ \\
\hline
\end{tabular}

A. Implementation of Halal Assurance System (HAS) in the soybean processing industry

One of the books in the Halal Assurance System (HAS) discusses the criteria that must be met by the industry, before the products produced are submitted for certification by LPPOM MUI. There are eleven criteria that must be met, as a form of Halal Assurance System (HAS) implementation in the company. As a consequence of meeting these criteria, the industry will get the status of the Halal Assurance
System (HAS). The criteria for the Halal Assurance System (HAS) status consist of $\mathrm{A}, \mathrm{B}$, and $\mathrm{C}$. If the status of $\mathrm{C}$ certification is obtained, then the products produced by industry cannot be certified. The industry must obtain a minimum value of $\mathrm{B}$. The results of research on the existing soybean processing industry in Cilegon City $(n=50)$ show the following.

1) Halal policy

Halal policy is very important because it is the company's commitment to produce halal products consistently. Halal policy must also be disseminated to all stakeholders including suppliers. Halal policy must still exist even if the industry is classified as a small industry. The results of the study indicate that there are several companies that have not established halal policies, top management has not yet set halal policies in writing, and halal policies are also not separate or are still integrated with other system policies that exist in the industry.

\section{2) Halal management team}

The halal management team is a group of people appointed by top management to be responsible for the planning, implementation, evaluation and continuous improvement of the Halal Assurance System (HAS) in the company. The Halal Management Team Coordinator is at least a Technical Manager and is preferred by a Muslim. In general, the halal management team has received education and training organized by LPPOM MUI. The results showed that the halal management team was made up of elements of family members, because the business process carried out was a small industry and the halal management team included all the parts involved in critical activities. However, the team's responsibilities have not been clearly defined.

\section{3) Training and education}

Training Procedures conducted by LPPOM MUI include training objectives and targets, schedules, participants, methods, material providers, material, documentation, evaluation and indicators of training graduation. The results showed that the industry had not yet participated in training continuously. The training that is attended is generally only once every two years, namely when applying for halal certification, as well as extending halal certificates.

\section{4) Material}

Some Raw Materials and Supplementary Materials used to produce products and become part of the product composition (ingredient) must be registered at the time of submission of halal certification. Materials must be registered including substitution materials, because all raw materials must be recorded and reported to the MUI fatwa commission. Material must not originate and contain material from: a) Pigs and their derivatives, b) Khamr (alcoholic drinks), c) Derivatives derived only by physical separation, d) Blood, e) Carcasses, f) Parts of the human body. Supporting Materials must also be registered. Auxiliary material is an ingredient that is used to help manufacture the product, but the material is not part of the product composition (ingredient). The results showed that all ingredients in the soybean processing industry were 
equipped with halal documents. Material also does not mix with unclean or unclean ingredients.

\section{5) Products}

Products are products that are registered for Halal certification, both end products and intermediate products. Some of the concerns in halal certification are product names and product packaging forms. Product names may not use names that refer to something that is forbidden in Islamic law. Some product names that cannot be halal certified include; a) The name of the product which is the product is the name of the devil, d) The name of the product that leads to things that cause sleaze, e) The name of the product which is words that have erotic, vulgar and pornographic connotations. Whereas forms that cannot be certified are a) forms of pigs and dogs, b) Forms of products with packaging that are erotic, vulgar or pornographic in nature.

\section{6) Production facilities}

All production facilities are registered. Production facilities may not be used interchangeably to produce halalcertified products and non-certified products that contain ingredients from pigs or their derivatives. Material and product storage facilities, including intermediate warehouses, must be able to prevent unclean contamination. Production facilities in the soybean processing industry in general use facilities that are easily found in the market. Such as soybean cooking, water storage, product storage, and products that are ready to sell. The results showed that the facilities in the production process mostly needed to be improved, starting from the humidity level, as well as the heat exposure to the soy cooking process. In additional it is necessary to improve the use of existing tools, so that dirt contaminants can be avoided. Production facilities in general need to be improved so that they are suitable for use as industrial processes.

\section{7) Written procedures for critical activities}

Written Procedures of Critical Activity is a set of standardized work procedures for controlling critical activities. Critical activities include: Selection of new materials, purchase of materials, product formulation (if any), inspection of incoming materials, production, washing of facilities and auxiliary equipment, storage and handling of materials or products and transportation. The scope of critical activities depends on the business processes of each industry. The results showed that not all soybean processing industries have a Standard Operating Procedure (SOP) for all critical activities carried out, so it is natural that no industry has obtained Halal Assurance System (HAS) status with category A. All new industries have HAS certificate status with category B.

\section{8) Treaceability}

Companies must have procedures to guarantee the traceability of certified products. The purpose of traceability is that it can always be proven that the certified product comes from materials approved by LPPOM MUI and is produced at facilities that meet the criteria established by LPPOM MUI.

\section{9) Handling of products that do not meet the criteria}

The industry must have written procedures for handling products that do not meet the criteria, which are already sold in the free market. A handling procedure is needed if a product is already produced from materials that are not approved by LPPOM MUI and or from facilities that do not meet the criteria. The way to handle if it is already a is not sold to buyers who require halal products, b) If already sold, then the product must be withdrawn, this product must not be reworked, downgraded, reformulated. The soybean processing industry is not yet optimal in making Standard Operating Procedures (SOPs) for handling products that do not meet the criteria.

\section{0) Internal audit}

Internal audit is an activity of verifying the fulfillment of eleven criteria conducted by auditors from the company (internal). Industry needs to have written procedures. The audit process is carried out by parties who are competent and independent of the area being audited. Corrective action must be determined in time and be able to resolve the weaknesses found and prevent the recurrence of those weaknesses in the future. Internal audit will be an input for the next stage (management review)

\section{1) Management review}

The review is an Assessment conducted by company management regarding the effectiveness of the implementation of Halal Assurance System (HAS) in the internal industry. Material review includes a) Results of internal and external audits of the industry, b) Improvements from previous reviews, c) Changes in conditions in the company. The results showed that the management review of the soybean processing industry in the city of Cilegon had not been carried out optimally and not all industries conducted a review, so that priority should be given to improvement.

The impact of halal product certification has been widely written by previous researchers $[16,17,18,19,20]$. The tentative conclusion is that the evaluation of the implementation of Halal Assurance System (HAS) -23000 in the soybean processing industry needs to be improved on the criteria of: a) Halal policy, b) production facilities, c) written procedures for critical activities, d) handling products that do not meet the criteria , and e) management review.

\section{B. Results of identification of ergonomic problems in the soybean processing industry}

Eight aspects of ergonomics are used as the initial framework for identifying ergonomic problems in the industry. These problems are then analyzed and recommendations for improvement of working conditions are given.

Based on table 2. it can be concluded that the problem of ergonomics lies in aspects: energy and nutrition, use of muscle, body posture, work environment, and humanmachine interaction. These five aspects need to get attention by industry management for immediate improvement. This improvement will improve employee performance. Improved employee performance has an impact on increasing work productivity. Some work improvements need to be based on the results of the analysis of human factors and the identification of the main problems first 
$[21,22,23]$. The concept of ergonomics is able to solve employee performance problems $[24,25,26]$.

TABLE II. SUMMARY OF ERGONOMIC PROBLEM (N=30 INDUSTRIES)

\begin{tabular}{|c|c|c|c|}
\hline & Aspect & Problem & $\begin{array}{l}\text { Recommendations } \\
\text { for improvement }\end{array}$ \\
\hline 1) & $\begin{array}{l}\text { Energy/ } \\
\text { nutrition }\end{array}$ & $\begin{array}{l}\text { - Food intake is not adjusted } \\
\text { according to BMR Rate } \\
\text { - The drink does not contain } \\
\text { isotonic }\end{array}$ & $\begin{array}{l}\text { Work nutrition } \\
\text { evaluation }\end{array}$ \\
\hline 2) & $\begin{array}{l}\text { Use of } \\
\text { muscle }\end{array}$ & $\begin{array}{l}\text { - Bowing attitude } \\
\text { - L5 / S1 injury } \\
\text { - Nordic body map complaints } \\
\text { - physical fatigue }\end{array}$ & $\begin{array}{l}\text { Rappid Upper } \\
\text { Limb Assessment } \\
\text { Analysis }\end{array}$ \\
\hline 3) & $\begin{array}{l}\text { Body } \\
\text { posture }\end{array}$ & $\begin{array}{l}\text { - Unnatural work attitude } \\
\text { - Uneconomic movements } \\
\text { - Need analysis of right hand } \\
\text { map and left hand map } \\
\text { - Not counting the maximum } \\
\text { lifting load }\end{array}$ & $\begin{array}{l}\text { Rappid Upper } \\
\text { Limb Assessment } \\
\text { Analysis }\end{array}$ \\
\hline 4) & $\begin{array}{l}\text { Work } \\
\text { environment }\end{array}$ & $\begin{array}{l}\text { - Temperature exposure } \\
\text { - extreme temperatures } \\
\text { - Need to evaluate humidity } \\
\text { - Need to evaluate angina } \\
\text { speed } \\
\text { - Environmental pollution } \\
\text { factors }\end{array}$ & $\begin{array}{l}\text { Evaluation of the } \\
\text { Threshold Value } \\
\text { of the working } \\
\text { climate }\end{array}$ \\
\hline 5) & $\begin{array}{l}\text { Time } \\
\text { condition }\end{array}$ & $\begin{array}{l}\text { - Setting working time and rest } \\
\text { hours } \\
\text { - Rescheduling production } \\
\text { scheduling time to fulfill } \\
\text { demand }\end{array}$ & - \\
\hline 6) & $\begin{array}{l}\text { Socio- } \\
\text { cultural }\end{array}$ & & - \\
\hline 7) & Information & & - \\
\hline 8) & $\begin{array}{l}\text { Human- } \\
\text { machine } \\
\text { interface }\end{array}$ & $\begin{array}{l}\text { - Redesign work facilities } \\
\text { - The use of anthropometry of } \\
\text { local workers }\end{array}$ & $\begin{array}{l}\text { Appropriate } \\
\text { Technology } \\
\text { Design }\end{array}$ \\
\hline
\end{tabular}

\section{Ability to adopt technology (technometric)}

The technometric model is used to calculate the coefficient value of technological contributions [27,28]. The most dominant technical ability that must be improved is Technoware, because it is at a value of 0.3 (scale $0-1$ ), while Humanware is at a value of 0.6 (scale 0-1), Organware value is 0.75) (scale 0-1), and Inforware is at a value of 0.8 (scale $0-1$ ). The highest adoption value is Inforware (I). This is because industries have groups to gather and exchange information. Online information is not yet needed, because the activities currently being carried out can include marketing needs. The second level is the adoption of technology in Organware $(\mathrm{O})$, due to sales activities and the supply of raw materials carried out in an organized manner, the desire to fulfill requests together is clearly visible. Business processes are carried out on a "partner" basis rather than "competition". Good organware is possible because of the support of Humanware $(\mathrm{H})$, the human factor has become a culture for mutual cooperation and partnership.

Identification of problems using 8 ergonomic aspects is complemented by a map of technoometric capabilities, potentially able to perfect the implementation of the Halal Assurance System (HAS)-23000 in Halal Certified processed soybean products in the city of Cilegon. The improvement referred to is in the form of work system improvement recommendations.

\section{CONCLUSION}

Based on the analysis and discussion, several ergonomic problems are known, namely: a) lack of attention to energy and nutrition, b) the use of muscles that do not consider the physiology of the human body (use of muscle), c) unnatural body movements (body posture), d ) hot working environment conditions ie workers exposed to high temperatures and the impact on excessive sweating so that the potential to contaminate food (work environment, d) use of equipment that still does not use worker anthropometry, (human-machine interaction).

Whereas the most dominant technometric ability map that must be improved is Technoware because it has the lowest level when compared to Humanware, Inforware and Organware.

The implementation of Halal Assurance System (HAS) -23000 needs to be improved, namely: a) Halal policies need to be upgraded according to the business processes carried out, b) production facilities need to be designed based on user anthropometry, c) written procedures for critical activities need to be written and carried out by all industrial employees, d) handling products that do not meet the criteria need to be made Standard Operating Procedure (SOP), e) management review needs to be done at least once a year. Identification of problems using 8 ergonomic aspects is complemented by a map of technometric capabilities, potentially enhancing the implementation of the Halal Assurance System (HAS) -23000 in Halal Certified processed soy products. The improvement in question is in the form of recommendations for improving ergonomicbased work systems.

\section{REFERENCES}

[1] Henderson, J.C. 2010. Islam and tourism: Brunei, Indonesia, Malaysia and Singapore. In: Scott N, Jafari J, editors. Tourism in the Muslim world. Book series: Bridging tourism theory and practice. Vol. 2. New York (US): Emerald Group Publishing Limited. p. 75-89.

[2] Spiegel, M.V. Fels-Klerx HJ, Sterrenburg, P. Ruth, S.M, ScholtensToma, I.M.J. Kok, E.J. 2012. Halal assurance in food supply chains: verification of halal certificates using audits and laboratory analysis. Food Sci Technol Trends. 27 (2): 109-111.

[3] Azis Y.A, Chok, N. V. 2013. The role of halal awareness, halal certification, and marketing components in determining halal purchase intention among non-Muslims in Malaysia: a structural equation modeling approach. J Mark Agribus Food Int. 25 (1): 1-23.

[4] Farook S, Shikoh R, Dur F, Adil M, Hasan S, Goud B, Evans S, Jazzareen F, Fitriati A, El-Shafaki R, Liu KP. 2013. State of the global Islamic economy 2013 report. New York (US): Thomson Reuters and Dinar Standard.

[5] Adiatmika, I.P.G. 2007. Improved working conditions with a total ergonomics approach reduce musculoskeletal complaints and fatigue and increase productivity and income of metal painting craftsmen in Kediri-Tabanan (written in Bahasa Indonesia). (Dissertation). Denpasar: Postgraduate Program at Udayana University

[6] Handari, A.L.M.I.S. 2013. Ergo-Psychophysiology decreases physiological responses, increases readiness, work ability and work engagement of employees of the Bali Hyatt hotel accounting department in Denpasar (written in Bahasa Indonesia). (Dissertation). Denpasar: Postgraduate Program at Udayana University.

[7] Muliarta, I.M. 2014. Improved computer working conditions reduce muscle tension, workload and subjective complaints of Visual Communication Design students at the Indonesian Arts Institute in Denpasar (written in Bahasa Indonesia). (Dissertation). Denpasar: Postgraduate Program at Udayana University 
[8] Purnawati, S. 2012. The application of an ergonomic-based work stress management program (Ergo-JSI) reduces the work stress of employees of the National X private bank in Denpasar, Bali (written in Bahasa Indonesia). (Dissertation). Denpasar: Postgraduate Program at Udayana University.

[9] Susihono, W. 2012. Technology Assessment to Determine Competitor Industry Position. J @ TI Undip, Vol VII, No 2, May 2012

[10] UNESCAP. 1989. Technology Atlas Project. A Framework for Technology Based Development: Technology Content Assessment \& Technology Climate Assessment. Vol 2

[11] Nazaruddin. 2008. Technology Management (written in Bahasa Indonesia). First edition. First printing. Graha Science: Yogyakarta.

[12] Pailin, D. B. 2013. Analysis of the contribution of technological components in the seaweed cultivation business in West Seram District (written in Bahasa Indonesia). ARIKA, 7 (1), p1-14.

[13] Pujianto, T. Hasbullah, R.A.S. Ardiansyah, I 2017. Evaluation of the Contribution of Technology Components in Production Activities at PT Z Using the Techometric Method (written in Bahasa Indonesia). Industria: Agroindustry Management and Technology Journal. Volume 6 No. 3: p133-144

[14] Khafidoh, M.S. Setyo, N. Hikmah, F. 2014. Technology Assessment of Inpatient Hospital Management Information Systems Using Technic and Smart Methods at the Lung Jember Hospital (written in Bahasa Indonesia). Indonesian Health Information Management Journal. Vol.2, No.1. March 2014. P74-81

[15] Indriartiningtias, R. Amijaya, R. Nugroho, W. 2014. Technology Assessment of 2 Skop Manufacturing Industries with Techometric Methods (written in Bahasa Indonesia). Metris Journal, 15 (2014): p89-96

[16] Fischer, J. 2008. Religion, science and market. EMBO Reports. 9 (9): 828-831.

[17] Evans AD, Evans, S. 2012. Halal market dynamic: an analysis. London (UK): Imarat Consultants.

[18] Prabowo, S. Abd Rahman, A, A.B. Rahman, S. Samah, A. 2015. Revealing factors hindering halal certification in East Kalimantan Indonesia. J Islamic Mark. 6 (2): 268-291

[19] Soesilowati, E.S. 2010. Business opportunities for halal products in the global market: Muslim consumer behavior and halal food consumption. JISSH. 3: 151-160.

[20] Wahid, N. 2012. Looking at halal products from the perspective of comparative advantage (written in Bahasa Indonesia). J Halal. 98: 3031.

[21] Susihono, W. 2014a. Ergonomics Approach Analysis as the Basis for Identification and Improvement of Working Conditions in the Induction Kitchen Metal Casting Industry; Case Study at PT. X Ceper Klaten (written in Bahasa Indonesia). Proceedings of the National Industrial Engineering Conference Seminar. Department of Industrial Engineering Sebelas Maret University. Surakarta Pages 284-290. ISBN 978-602-70259-2-9.

[22] Susihono, W. 2014b. Hazard and Risk Assessment in the Induction Furnace Metal Casting Industry; Case Study at PT. X Ceper Klaten (written in Bahasa Indonesia). Proceedings of the National Industrial Engineering Conference Seminar. Department of Industrial Engineering Sebelas Maret University. Surakarta Pages 274-283. ISBN 978-602-70259-2-9.

[23] Susihono, W. 2014c. Evaluation of Workload and Musculoskeletal Complaints of Workers in Metal Casting Company X Induction Kitchen System (written in Bahasa Indonesia). Proceeding Industrial Engineering National Conference (IENACO). Industrial Engineering Study Program, FT Muhammadiyah University, Surakarta. Pages 9198. ISSN 2337-4349.

[24] Adiputra, N. Sutjana, D.P. Suyasning. Tirtayasa, K. 2001. Musculoskeletal disorders of employees of several small companies in Bali (written in Bahasa Indonesia). Indonesian ergonomics journal. 2 (1.6): 6-9.

[25] Kaplan, M. 2004. Introduction: Adding A Cutural Dimension to human Factors. In Kaplan, ed. Cultural Ergonomic. Amsterdam Elsevier.

[26] Sutjana, I.D.P. 2014. Occupational Diseases. Collection of Ergonomics Papers (written in Bahasa Indonesia). Potpourri. Volume 2. Denpasar: Postgraduate Program. Udayana University.
[27] Yanthi, E. R. 2018. Analysis of the Contribution of Technology Components (Technoware, Humanware, Infoware, Orgaware) in the Railway Freight Services Company with the Techometric Model Approach (written in Bahasa Indonesia). (Dissertation). Bogor Agricultural University Postgraduate School.

[28] Apriyantono, A. Nurbowo, 2003. Guide to Halal Shopping and Consumption (written in Bahasa Indonesia). Jakarta: Khairul Bayan. p68-69. 